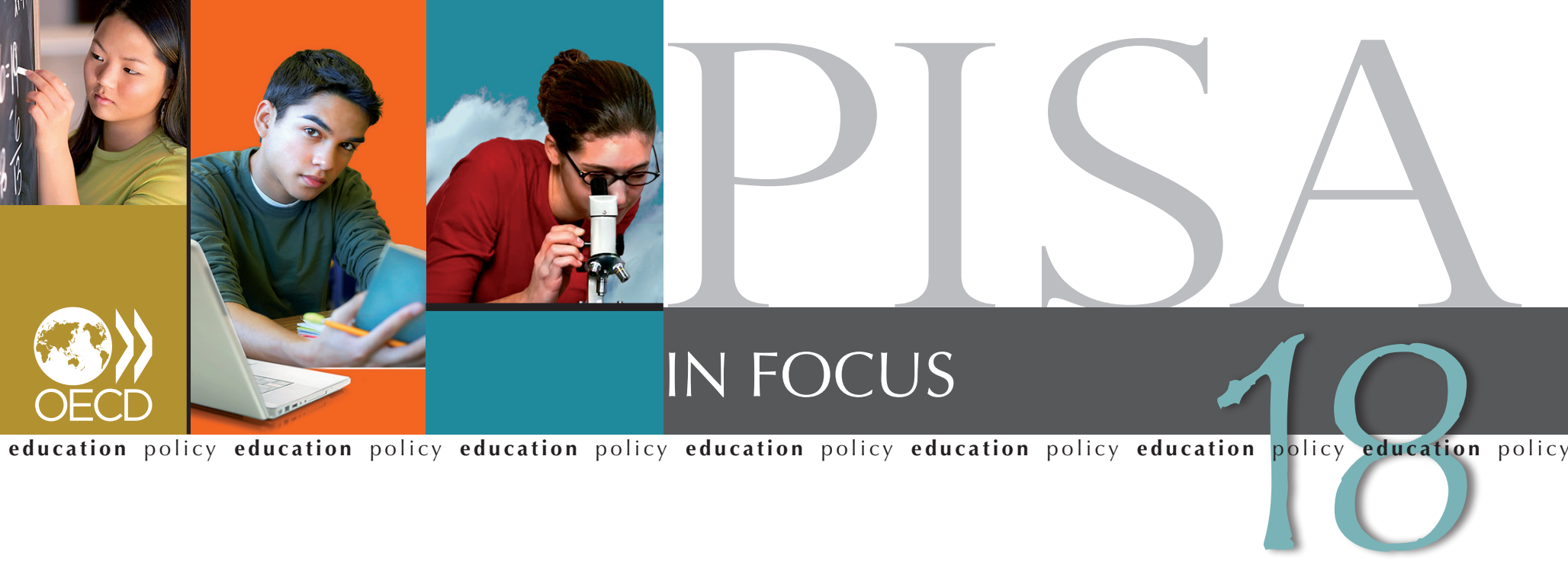

\title{
Are students more engaged when schools offer extracurricular activities?
}

- Around $90 \%$ of students in OECD countries attend schools that offer field trips to places where students can learn about scientific principles and concepts.

- In most countries, science-related extracurricular activities at school are related to better student performance, a stronger belief by students in their abilities to handle science-related tasks, and greater enjoyment of learning science. And, in many countries, this is true even after accounting for the socio-economic background of both students and schools.

Science project. The very phrase is nearly synonymous with hands-on learning, learning-by-doing, collaboration. Are students more engaged and do they perform better in science if their school encourages them to work on science projects, participate in science fairs, belong to a science-related club or go on science-related field trips in addition to teaching them the mandatory science curriculum? To find out, PISA 2006 asked school principals about what kinds of extracurricular science activities they offered their students and linked their responses with students' performance on the PISA science test.

The types and availability of enrichment activities vary widely...
Across OECD countries, $89 \%$ of students attend schools whose principals reported that science-related field trips were commonly offered. In Australia, the Czech Republic, Estonia, Hungary, Italy, Poland, the Slovak Republic, Slovenia and the partner countries Latvia, Lithuania, Qatar, Romania, the Russian Federation and Thailand, more than $96 \%$ of students attend such a school; but in Japan, only 30\% of students do. In Poland, all students attend schools that hold science competitions, according to their principals; while more than $97 \%$ of students in Australia and the partner countries Kyrgyzstan and the Russian Federation do, too. On average in OECD countries, 56\% of students attend schools that hold science competitions. These kinds of competitions are not as popular in Japan, where just $6 \%$ of students attend such schools, Denmark (10\% of students) and Norway (16\% of students). Extracurricular science projects, science fairs and science clubs are less prevalent across OECD countries: on average, $48 \%$ of students are in schools that encourage involvement in extracurricular science projects, $42 \%$ are in schools that organise science fairs, and $41 \%$ are in schools that have science clubs. 


\begin{tabular}{|c|c|c|c|c|c|c|}
\hline & \multicolumn{5}{|c|}{$\begin{array}{l}\text { Percentage of students whose schools } \\
\text { promote engagement with science using: }\end{array}$} \\
\hline & & 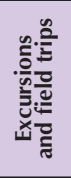 & 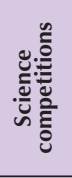 & 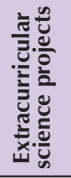 & 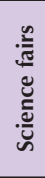 & 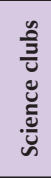 \\
\hline & & \multicolumn{5}{|c|}{$\%$} \\
\hline \multirow{34}{*}{$\begin{array}{l}\text { U్ } \\
\text { ou } \\
\\
\\
\\
\end{array}$} & Australia & 97 & 98 & 70 & 31 & 31 \\
\hline & Austria & 91 & 35 & 30 & 27 & 27 \\
\hline & Belgium & 91 & 52 & 48 & 35 & 5 \\
\hline & Canada & 95 & 64 & 64 & 55 & 48 \\
\hline & Chile & 74 & 36 & 47 & 44 & 39 \\
\hline & Czech Republic & 97 & 78 & 50 & 61 & 47 \\
\hline & Denmark & 87 & 10 & 18 & 25 & 3 \\
\hline & Estonia & 97 & 88 & 88 & 81 & 50 \\
\hline & Finland & 94 & 37 & 23 & 9 & 9 \\
\hline & Germany & 95 & 43 & 34 & 29 & 47 \\
\hline & Greece & 87 & 67 & 23 & 9 & 11 \\
\hline & Hungary & 97 & 84 & 38 & 69 & 72 \\
\hline & Iceland & 95 & 25 & 23 & 7 & 5 \\
\hline & Ireland & 93 & 54 & 53 & 64 & 21 \\
\hline & Israel & 87 & 62 & 65 & 32 & 53 \\
\hline & Italy & 96 & 34 & 75 & 16 & 39 \\
\hline & Japan & 30 & 6 & 19 & 11 & 49 \\
\hline & Korea & 80 & 86 & 44 & 49 & 87 \\
\hline & Luxembourg & 93 & 41 & 56 & 69 & 33 \\
\hline & Mexico & 75 & 72 & 54 & 39 & 21 \\
\hline & Netherlands & 89 & 35 & 40 & 21 & 8 \\
\hline & New Zealand & 94 & 91 & 57 & 72 & 32 \\
\hline & Norway & 94 & 16 & 42 & 36 & 1 \\
\hline & Poland & 99 & 100 & 51 & 27 & 78 \\
\hline & Portugal & 94 & 62 & 86 & 62 & 64 \\
\hline & Slovak Republic & 99 & 81 & 44 & 70 & 78 \\
\hline & Slovenia & 97 & 80 & 79 & 85 & 92 \\
\hline & Spain & 95 & 37 & 36 & 57 & 69 \\
\hline & Sweden & 81 & 56 & 29 & 24 & 7 \\
\hline & Switzerland & 95 & 22 & 29 & 47 & 35 \\
\hline & Turkey & 78 & 54 & 48 & 29 & 39 \\
\hline & United Kingdom & 87 & 72 & 60 & 35 & 73 \\
\hline & United States & 92 & 58 & 65 & 50 & 73 \\
\hline & OECD average & 89 & 56 & 48 & 42 & 41 \\
\hline \multirow{22}{*}{$\frac{\square}{\tilde{J}}$} & Argentina & 80 & 51 & 65 & 72 & 16 \\
\hline & Azerbaijan & 91 & 79 & 29 & 42 & 68 \\
\hline & Brazil & 84 & 39 & 86 & 82 & 5 \\
\hline & \begin{tabular}{|l|} 
Bulgaria \\
\end{tabular} & 86 & 78 & 52 & 20 & $\mathrm{a}$ \\
\hline & Chinese Taipei & 89 & 72 & 71 & 73 & 76 \\
\hline & Colombia & 87 & 62 & 75 & 71 & 93 \\
\hline & Croatia & 90 & 75 & 58 & 49 & 21 \\
\hline & Hong Kong-China & 90 & 91 & 83 & 52 & 91 \\
\hline & Indonesia & 74 & 63 & 45 & 25 & 60 \\
\hline & Jordan & 90 & 75 & 84 & 80 & 67 \\
\hline & Kyrgyzstan & 94 & 98 & 36 & 75 & 79 \\
\hline & $\begin{array}{l}\text { Latvia } \\
\end{array}$ & 99 & 91 & 86 & 6 & 14 \\
\hline & Lithuania & 99 & 91 & 76 & 98 & 80 \\
\hline & Macao-China & 69 & 91 & 96 & 34 & 46 \\
\hline & Montenegro & 83 & 81 & 57 & 31 & 68 \\
\hline & Qatar & 97 & 78 & 71 & 66 & 41 \\
\hline & Romania & 100 & 92 & 55 & 62 & 71 \\
\hline & Russian Federation & 99 & 98 & 80 & 83 & 84 \\
\hline & Serbia & 65 & 84 & 43 & 41 & 83 \\
\hline & Thailand & 96 & 93 & 89 & 97 & 84 \\
\hline & Tunisia & 78 & 49 & 51 & 56 & 83 \\
\hline & Uruguay & 83 & 32 & 60 & 57 & 33 \\
\hline
\end{tabular}

Source: OECD, PISA 2006 Database.
... but their association with better student performance is consistent.

In most countries, students in schools that offer more science-related extracurricular activities tend to perform better in science than do students in schools that offer fewer such activities. This is the case in 22 of 31 OECD countries and 14 of 17 partner countries and economies with available data.

The strongest relationship is found in Germany, where $15 \%$ of the variation in student performance in science can be accounted for by the availability of science-related extracurricular activities in the schools, and in Australia, where 13\% of the variation in student performance can be explained in this way.

In 21 OECD countries and 12 partner countries and economies, the positive relationship between the availability of these kinds of activities at school and student performance in science holds even after accounting for students' socio-economic background. But in the United States, students in schools that offer fewer of these kinds of science-related activities tend to perform better in science, after accounting for the students' socio-economic backgrounds, while in Montenegro, the relationship is negative both before and after accounting for students' backgrounds. 
Even after accounting for the average socio-economic background of both schools and students, in eight OECD countries, four partner countries and one partner economy, on average, students in schools that offer more extracurricular activities tend to perform better than those in schools that offer fewer such activities. In many countries and economies, the performance advantage of schools that offer more science-related extracurricular activities disappears after accounting for the socio-economic backgrounds of students and schools. This is because the schools that offer more of these kinds of activities also tend to be socio-economically advantaged and, in turn, tend to benefit from other features that are also related to higher scores on the PISA surveys.

The benefits are seen in students' attitudes, too.

Students in schools that offer more science-related extracurricular activities tend not only to perform better in science, but also to report more positive attitudes towards science. They believe in their own ability to handle science-related tasks effectively (known as self-efficacy) and they enjoy learning science. Self-efficacy and enjoyment are important in learning, as these have been shown to have considerable impact on the way students set goals and use learning strategies. In 22 OECD countries, 7 partner countries and 1 partner economy, students in schools that offer more of these kinds of activities tend to have higher levels of self-efficacy in science; and in 20 OECD countries, 2 partner countries and 1 partner economy, they also enjoy learning science more.

Source: OECD, PISA 2006 Database.

Note: Analyses examining the association between science-related extracurricular activities and performance in science, science self-efficacy and enjoyment of science were developed using a composite index of school activities to promote the learning of science.

See OECD, PISA 2006: Science Competencies for Tomorrow's World, Volume II: Data, Table 5.18

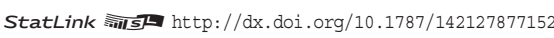

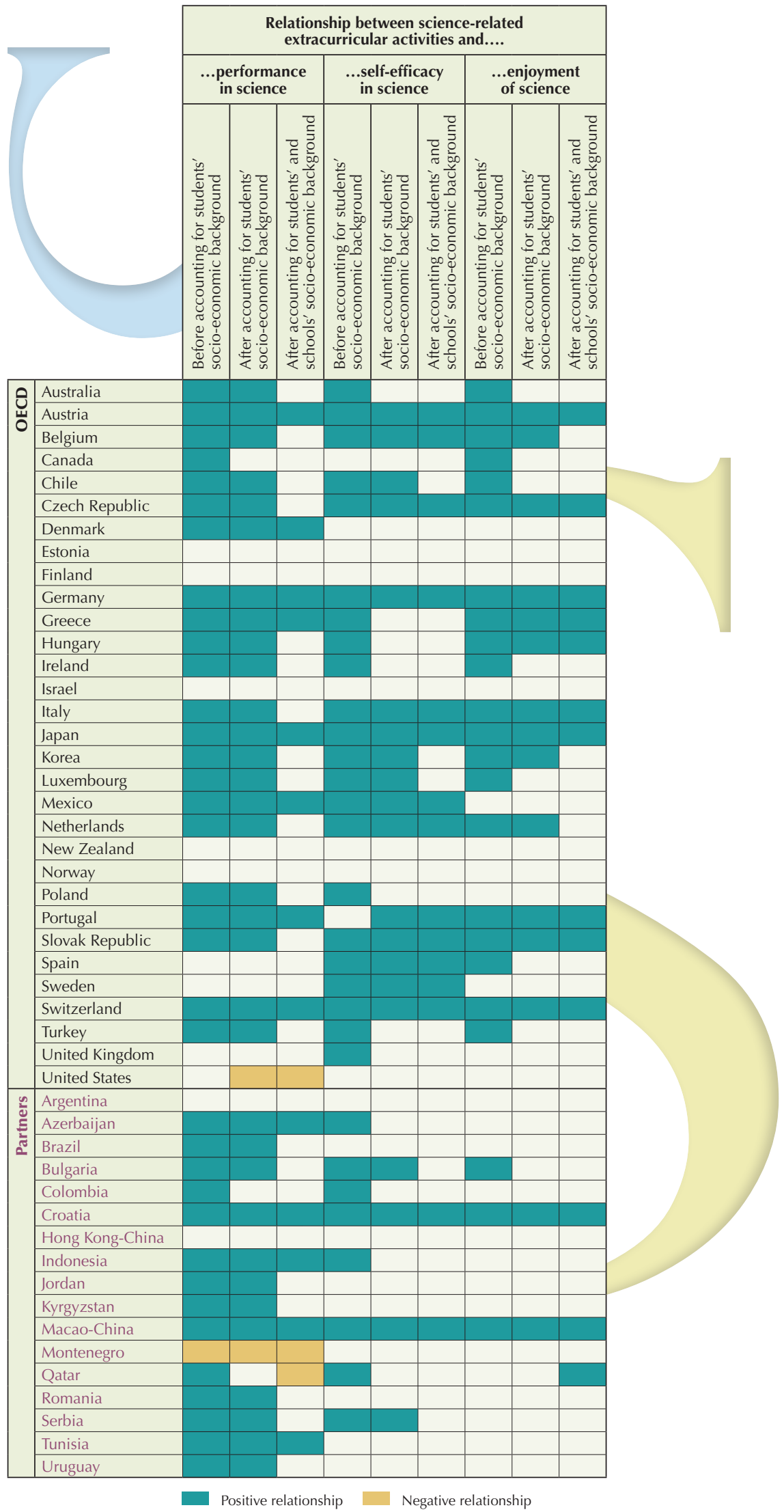


After accounting for the socio-economic backgrounds of students and schools, the positive relationship with self-efficacy holds in 13 OECD countries, 1 partner country and 1 partner economy, and the positive relationship with enjoyment of learning holds in 10 OECD countries, 1 partner country and 2 partner economies. In no country or economy is there a negative relationship between science-related extracurricular activities and positive attitudes towards learning science.
To determine a student's level of self-efficacy in science, PISA asked students about their ability to: $i)$ recognise the science question that underlies a newspaper report on a health issue; ii) explain why earthquakes occur more frequently in some areas than in others; iii) describe the role of antibiotics in the treatment of disease; iv) identify the science question associated with the disposal of garbage; v) predict how changes to an environment will affect the survival of certain species; vi) interpret the scientific information provided on the labels of food items; vii) discuss how new evidence can lead to a change of understanding about the possibility of life on Mars; and viii) identify the better of two explanations for the formation of acid rain. Students were asked to choose one of the following responses: "I could do this easily"; "I could do this with a bit of effort"; "I would struggle to do this on my own"; or "I couldn't do this".

To determine a student's enjoyment of science, PISA asked students to indicate their level of agreement with the following statements: i) I generally have fun when I am learning science topics; ii) I like reading about science; iii) I am happy doing science problems; iv) I enjoy acquiring new knowledge in science; and v) I am interested in learning about science. Students were asked to choose one of the following responses: "strongly agree"; "agree"; "disagree"; or "strongly disagree".

The bottom line: PISA cannot determine whether being exposed to science-related extracurricular activities enhances students' attitudes towards science or whether students with more positive attitudes towards science are attracted to schools that offer more of such activities; both could be true. But what PISA does show is that these kinds of activities have a positive relationship not only to student performance, but also to students' attitudes towards learning and their belief in their own abilities.

\section{For more information}

Contact Miyako Ikeda (Miyako.Ikeda@oecd.org)

See PISA 2006: Science Competencies for Tomorrow's World, Volume I: Analysis, OECD Publishing; PISA 2006: Science Competencies for Tomorrow's World, Volume II: Data, OECD Publishing.

\section{Visit}

www.pisa.oecd.org www.oecd.org/pisa/infocus
Coming next month

Is there really such a thing as a "second chance" in education? 